\title{
フイリツピン向け電父製鍓設備の輸出について
}

$\begin{array}{llll}\text { 会員 } & \text { 野 } & \text { 田 } & \text { 浩 } \\ \text { 会 } & \text { 中 } & \text { 阔 } & \text { 章 }\end{array}$

\section{EXPORT OF ELECTRIC \\ STEEL MANUFACTURING PLANT \\ FOR PHILIPPINES}

\section{BI H. NODA \& A.NAKAOKA \\ Ohe Plant, Daido Steel Co.}

Recently we have finished export of the electric steel manufacturing plant for Philippines.

The customer is Messrs. Marcelo Steel Corp. at Molabon, Rizal, Philippnes.

The president, Mr. Jose P. Marcelo also owns Marcelo Rubber and Latę Products, Inc.

It is said that this electric steel manufacturing project is the first and the largest in Philippines.

Their steel melting and rolling plant is located at Punta Sta. Ana, Manila and is scheduled to have the capacity of producing of 30,000 tons of $1 / 4$ inch wire rod or the equivalent of the various concrete bar annually.

- The plant equipments contracted with us consist mainly of three 2 tons electric arc furnaces with three of $1,000 \mathrm{KVA}$ transformer, automatic current regulator amplidyne system and other necessary machineries and eguipments including refractories, electrodes, and laboratory eguipment.

At the same time brick manufacturing plant eguipment was purchased from us.

For the purpose of handling these, several engineers and technicians have been studying manual practice at the steel making and rolling shops of our Hosizaki plant here in Nagoya since october, 1950.

Now we hope Mr. Marcelo of the earlier completion of his grand project and successful operations there.

內

容

1 緒音

ii 其の他の設借

1 経 過

V 压延工場設嘴

17 先) 50 概要

11. 整瓦工場設備

III 雪気等鋼設備

III技術者教育

听- $\mathrm{i}$ 電 気 炉

vi結

言 
I 耤 言 (Foreword)

戦後貿易振興の一環としてブラント榆出り線 が主務官庁を始めとして，一般業界に於いて唱 道されて灹た。東南アジア経済開発を目的とし て年来各地てその会合肪催されてるる ECAFE 所謂ブジア経済会議の指導上相俟つて，イン ドフフィリツビン始め当該各地よりの引合い， 技術者来訪は近来著るしく増就しアアジフ工業 化の息吹きをひしひしと感ずるものである。当 社は既にインド，マドラス州に公大な鉱山，耕 地，工場を所有する SRI RAMA MACHIN

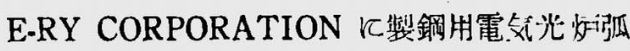
DSS-3,000（究量 3tons）を納入し，先方招 聘に依り製鋼関係技師を派遣し，工場建設，製

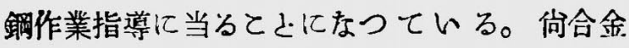
鉄，カーバイド製造用ハイロツトフフラントと して 4,000 KVA の密閉型ゼーダーベルグ式電 気炉を契約した。

本年 6 月表記フイリツピン，マルセロ製鋼社 (Marcelo Steel Corporation in Philippines) に以下に述へる製鋼攻び湅瓦製造ブラント一式 を輸出した。其の他同しくフイリツピンの National Development Company, Pacific Oxygen \& Acetylene Company 等上の折衝 も准んで居り，今後東南アジア地方へのフラン 卜輸出增加と云ら観点加ら敢て本輸出の全貌を 発表紹介し大方諸賢の参考供すると共沉斯界 の発展を行らんとするものである。

I 経 调 (Process in negotiation)

Marcelo Steel Corp. \& Mr. Jose P. Marcelo 氏の経営する Marcelo Rubber and Latex Products Corp. の事業に引続き, 其の経営の一環である Nail plant 事業の抬張 として戦後計画, 建設中のものであつてフィリ ツピン樶初の電気製鋼工場であり，又同時に最 大の製鋼所でもある。昨年春マニラより該补代 表 Mr. Antonio A. Maclan 来日, 次いで先 方技術顧問 Mr. Michael D. Yastreboff 着 京, 数ヶ月に亘る折衝す後同年10月末調印を完 了した。此の点先方の周密度調查もさるとと午
ら，、ニラー帯に電力低給権を持つているアメ リカ瓷本の Meralco Power Company 功 霍力を得るのに困難を感していた様である。

\section{1 先方の概要}

(Outline of Marcelo Steel Corp.)

年間 30,000ton の棒鋼及び線材製造を目標之 しナ:該社は下記の商社之垫的し，各社夫ヶ汇を の榆出を完了した。

品名サフライヤ メーカー

建家関係 新日本通商(株) 三菱地所(怢)

製鋼関係 西川廉業（株）新大同製鋼(株)

旦延関係 新日本通商(株) 芝浦共同工業(株)

新しく建設の製鋼，些延工場はマニラ市の

Punta, Sta. Ana 上云万所で符1図は工場所在

第 1 図

MARCELO STEEL CORPORATION附近の地図

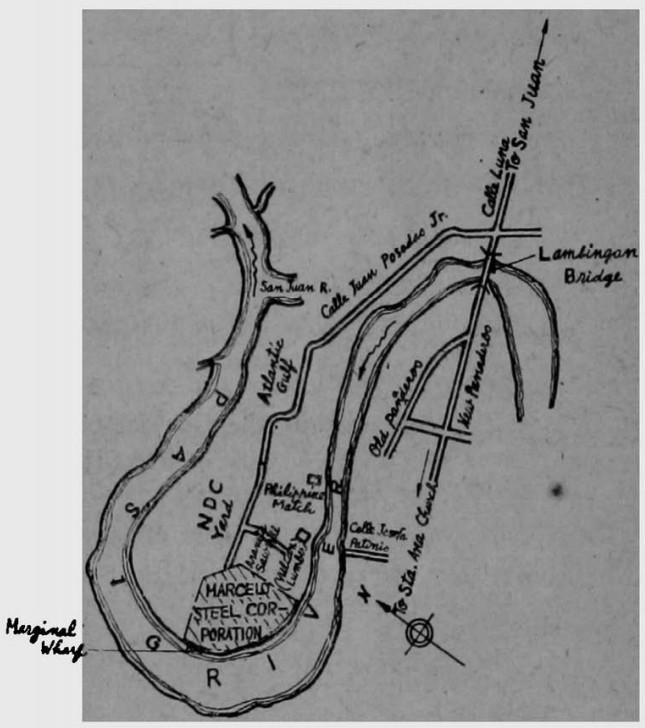

場所を，第2冭は工場建物の配置を，第3図は新 工場の鳥瞰図(三菱地所株式会社，建筑部設計） で多少の変更が後程行かれた。

\section{III 電氣製鋼設借}

(Electric Steel Making Plant)

当社は $3 \%$ : 争 $\times 5^{\prime}$ 長の普通鋼塊を年間 9,000 ton 生䞍す方計画の下に 2ton 電父泒光 炉 3 台を主休上する下記電気製鋼設供一式を納 入した。 


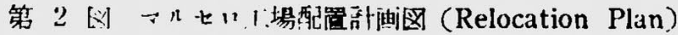

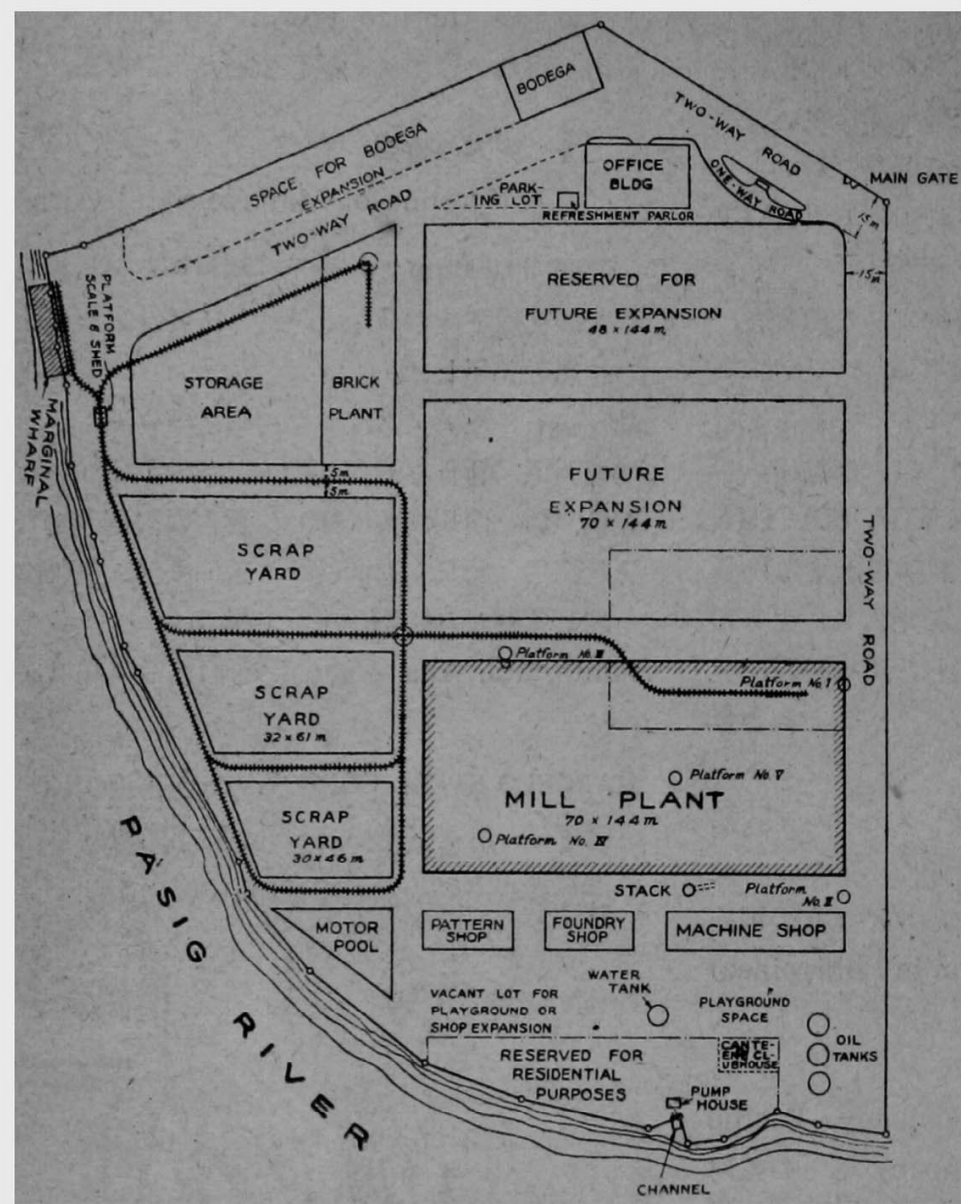

Situated in the District of STA ANA City of MANILA ISI,AND of LUZON

Containing an area of $80,001.3 \mathrm{~m}^{2}$

1. 2 トン電茹弧光非（製鋼用）

(2ton Electric arc furnace for steel making )

1,000KVA 窈生器, テンン゙リダイン自動 電流調整装通付)

2. 原料粉砕装置 (Raw material crusher)

3. インゴツト疪取装置（Ingot cleaning equipment)

4. 補機改附属装政

(Auxiliaries and accessories)

5. 耐火物 (Refractories)

6. 瓷 極 (Electrodes)

第１図注上記設借す配㯰を示している。

姑くである。 闪用,

量：1,000KVA

自動夕ツプ切換器付

(3) リアクトル

\section{刅一i 電氣妒}

(Electric Arc

Furnace)

(1) 電疑接本体 3 基

第 5 , 第 6 図は納入電 気炉を亦すが，その性 能, 要目等は次の如くで ある。

用途：電知製銀 用

型式：エル一式 冷材装入, DSS2,000 塩基 性又は酸性

公称容重： $2,000 \mathrm{~kg}$

装入容量： 2,000 $3,000 \mathrm{~kg}$

炉体外径：䄪 2,500 $\mathrm{mm}$

最高高サ： 約 5,000 $\mathrm{mm}$

(2) 沪用洨生器

3 基

第 7 図は炬用永玨器を 示す少，乙口仕様は次可

型式： 3 相, 60 サイクル, 油入自泠烒, 屋

電生： 1 次 $2,400 \mathrm{~V}$

2 次 156/139/125（一次デルタ結 線时）

90/80/72（二次久夕一結線り時）

定格：速続，温度上暑 $50^{\circ} \mathrm{C}$ (抵抗法)

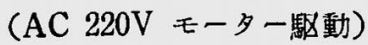

リテクトルは $35 \%$ で次の三つに分れる。 


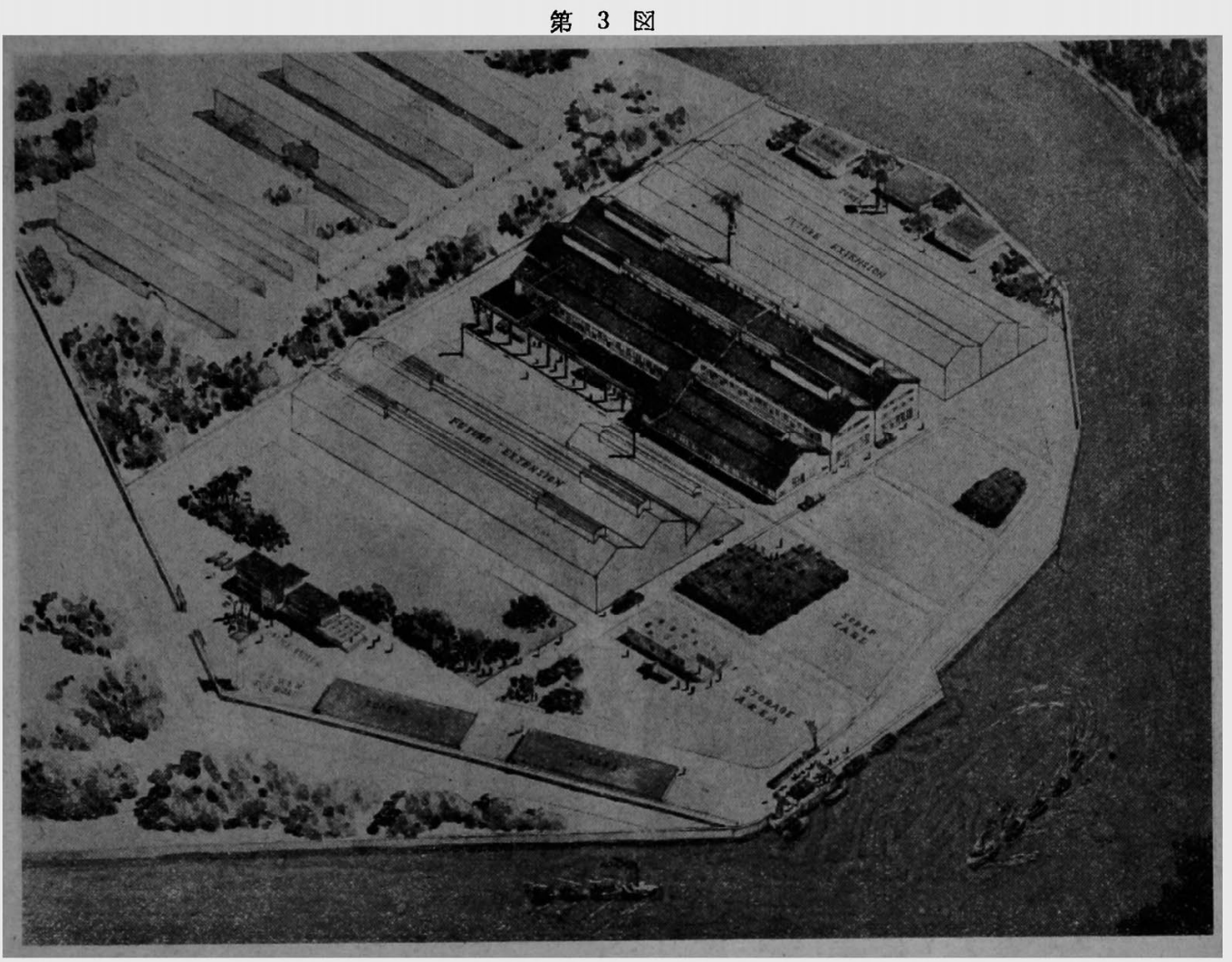

第 4 図鐜龬圧延工場配置図

\section{(ARRANGMENT PLAN OF ELECTRIC STEEL·MAKING AND ROLLING MILL PLANT)}

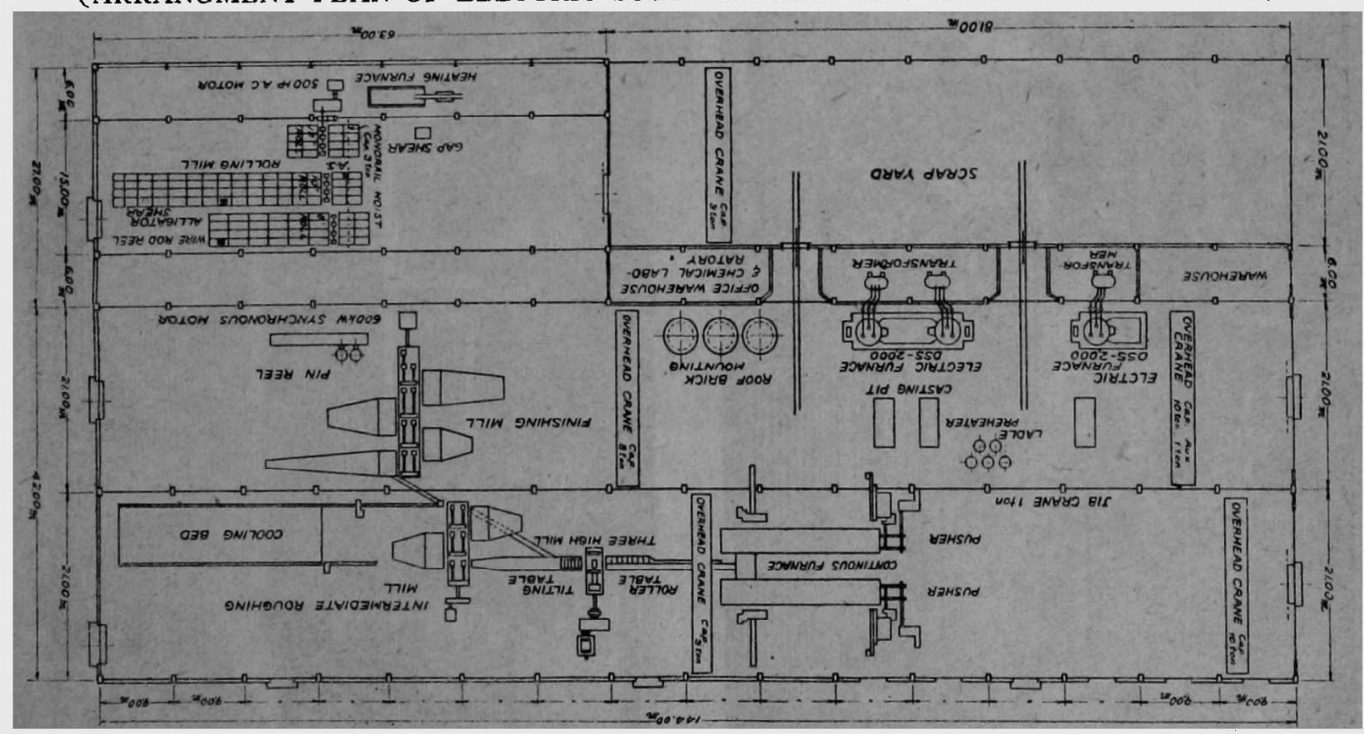

\section{a) $200 \mathrm{KVA}$ リアクトル}

変圧器江内藏, 自動タッブ切热器付 ( A C

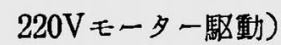

リアクチヴ電圧降下 480/360/240/120V

b) 150KVAスターテイングリナクトル 3 基 外置き, 自動タッブ切換器付, $(\mathrm{AC} 220 \mathrm{~V}$ 
第 5 国

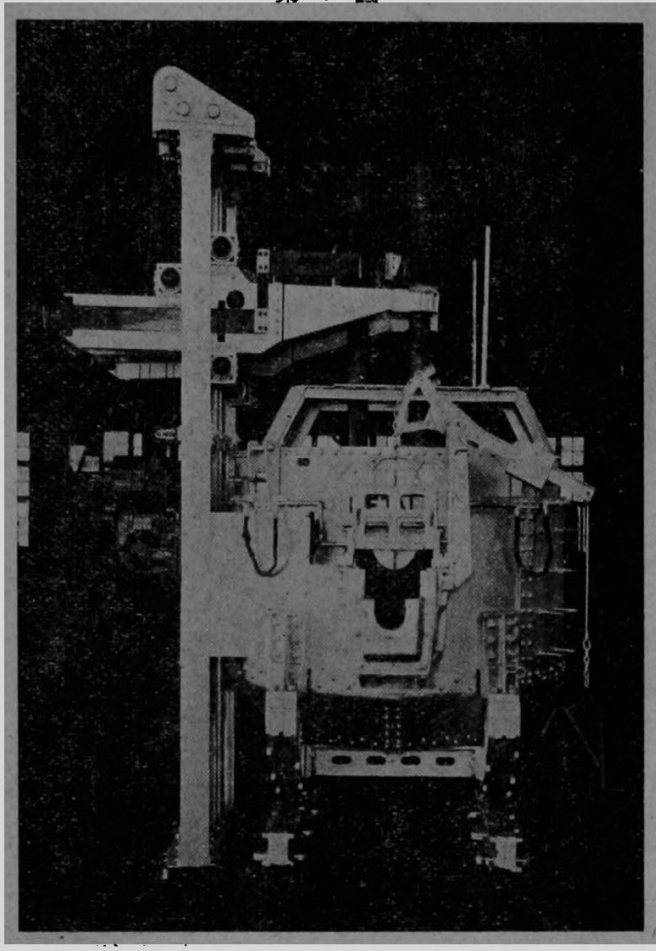

第 7 図

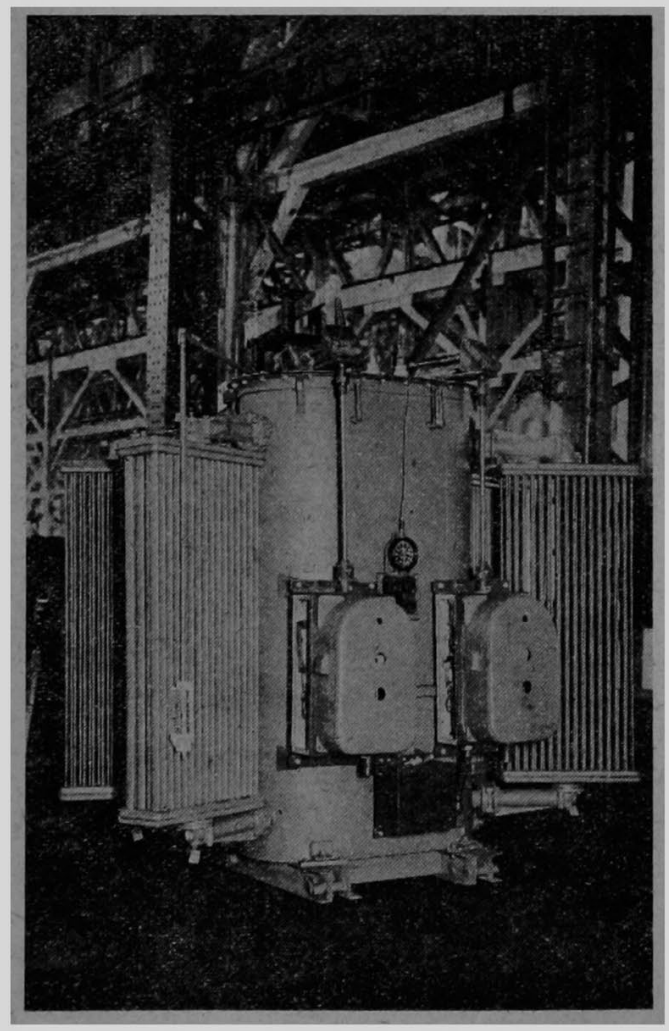

第 6 図

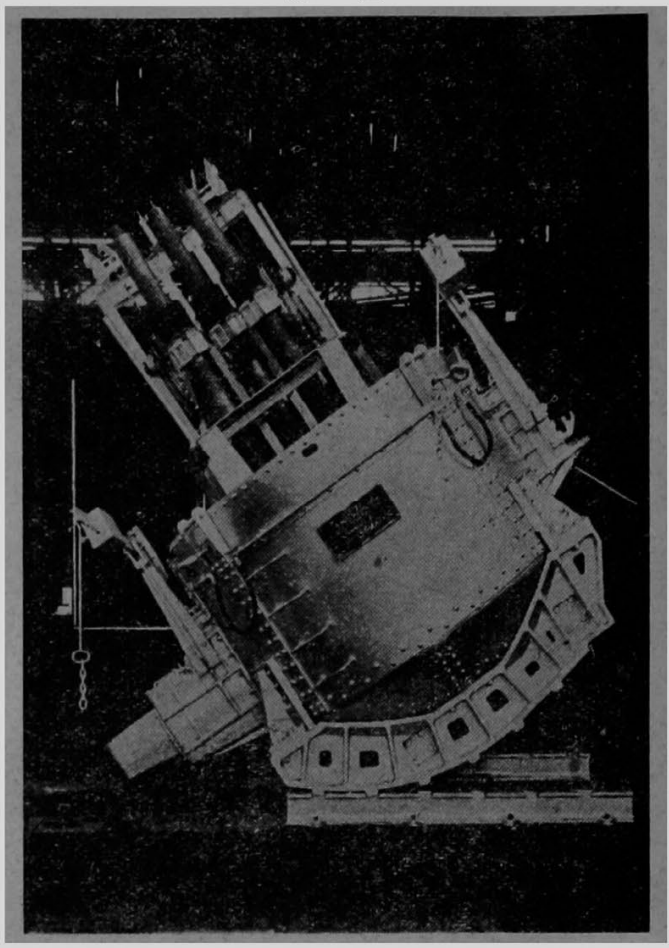

第 8 図

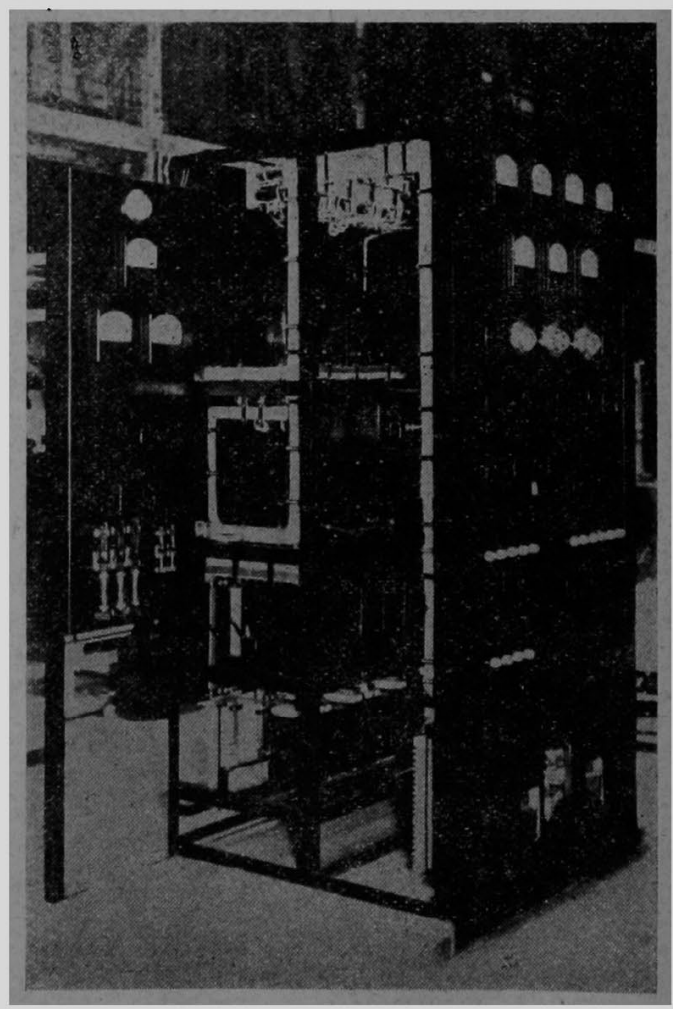


昭和 27 年 1 月(1952)]

$$
\text { モータ一駆動) }
$$

リデクチヴ電任降下 $208 / 139 / 70 / 0 \mathrm{~V}$

之は前記 Meralco 会社が35\%以上のリアク タンスを給電り条件よして装請して来た為りり のであつて，標準としては必要がない。

\section{（4）炬制御用配電盤 3 面}

第 8 図は受電盤を兼ねた炉制御盤で，アンフ リダイン式自動電流調整装置の調整部分を取付 けたものである。向つて布侧に細長く見える艋 はアンフリダイン用配電盤である。

\section{（5） アンフリダイン增巾発電機 3 組}

第 9 図はフンフリダイン 3 台，駆動肞ヒーータ

\section{第 9 図}

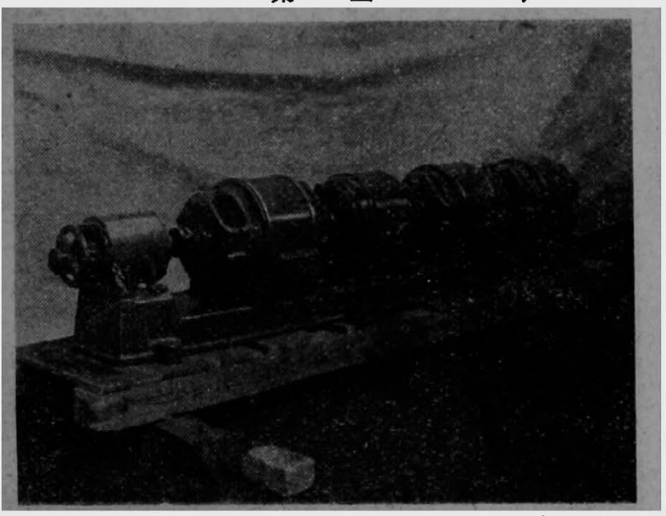

第 10 因電気弧光恦自動電流調整装置説明园

(アンプリダイン式、図け1相の䛨細を示す）

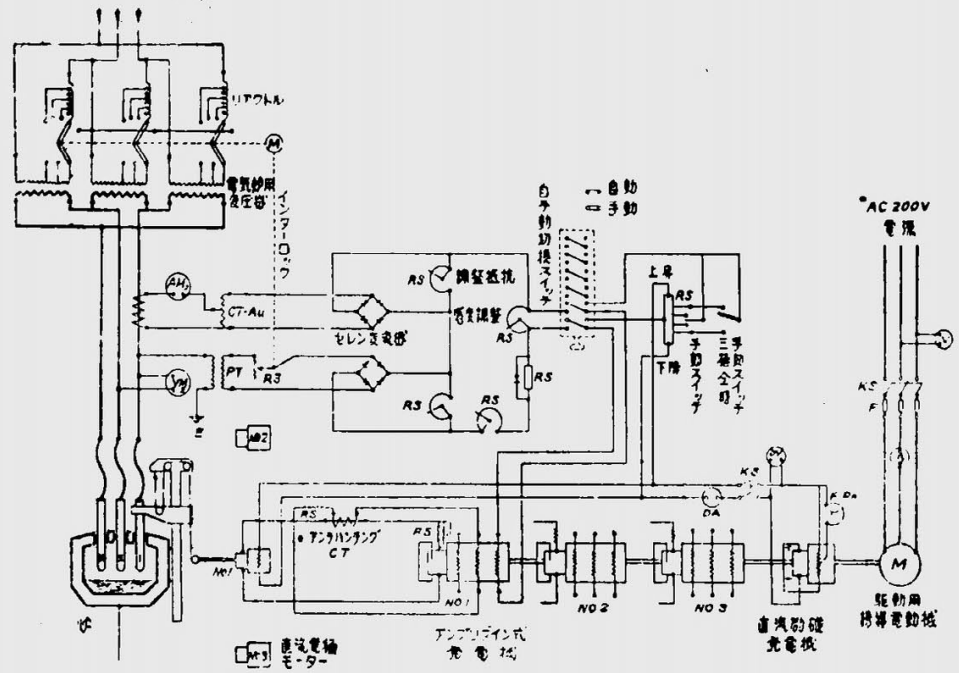

ー 1 台励磁機 1 台をコモンシャフトに取付けケ もので, 性能は次の通りである。（写真左から 励磁機一アンフリダイン一唀奨䉓動機一テンプ リダインーナンブリダート

a) テンブリダイン

開放型-- DC110V-1.5kw--1800r.p.m.

b) 三相誘蒈電動機

$4 \mathrm{P}-60 \mathrm{cy}-10 \mathrm{HP}-\mathrm{AC} 220 \mathrm{~V}-1.800$ r.p.m

c) 励 磁 機

DC110V $-0.5 \mathrm{kw}-1,800$ r.p.m.

之に依つて駆動せられる電極用淔流電動機す性 能は

全密閉型-4P-1kw-DC110V 1,200r.p.m.

\section{（6） アンブリダイン式電流調整装置}

此のアンブリダインは既に圧延機，製紙機械 等の制衘装置として各方面に活用されている が，電気炉用に本邦に於て使用さ扎始めてから は日快だ浅く此の点，今回の䠼出設萑の特長の 一つをなするのである。即ち徒来の電気式自動 電流装置に於いて，故障の原因亡なるとよの多 かつた電磁開閉器の接点の必要なく，处転機友 び調整抵抗化代り，界磁堂線への入力口僅度恋 化か短絡刷于をを経て二段底增巾されて数万倍る の出力変化となる為電弧 炉回路に㖪つた僅な電 压, 電流の変化が電極昇 降用モーターの回転とな つて現われ極めて効果的 方自動電流調整装置であ る。第 10 园は本装置の 電效的接続の略図であ る。

笔気設備は東京芝浦電 気株式会社製である。

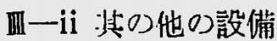
(Other equipments)

A. 原料粉砕装置

a) ブレーキクラツシ ヤー(第11図) 1 台 
型 $\mathrm{I}: \mathrm{CB}-3$

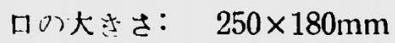

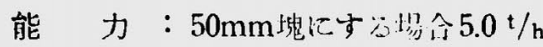
$25 \mathrm{~mm} \quad 2.5 \mathrm{t} / \mathrm{h}$ $15 \mathrm{~mm} \quad 1.5 \mathrm{t} / \mathrm{h}$

モーター : 7.5HP

第 11 図

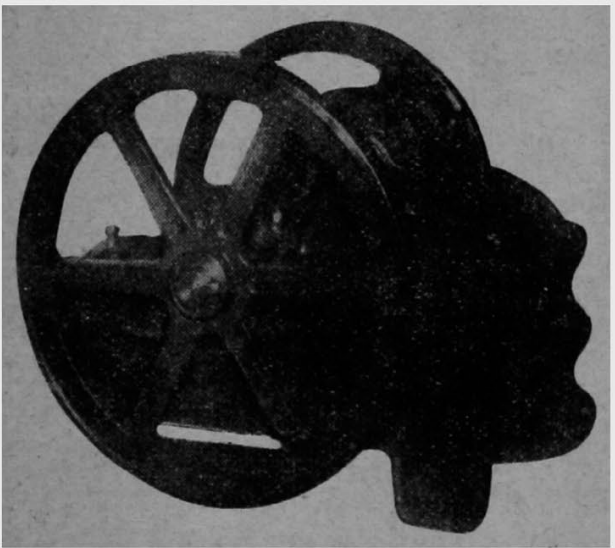

b）フレツト・ミル(第12図） 1 台

型式: $\mathrm{CF}-24$

ハンの直徍： $2,000 \mathrm{~mm}$

トレッド・ホキールの寸法： $300 \mathrm{~mm}$

巾 $\times 1,000 \mathrm{~mm}$ 径

能力: $5 \mathrm{t} / \mathrm{day}$

モーター： $12.5 \mathrm{kw}$

第 12 [ ]

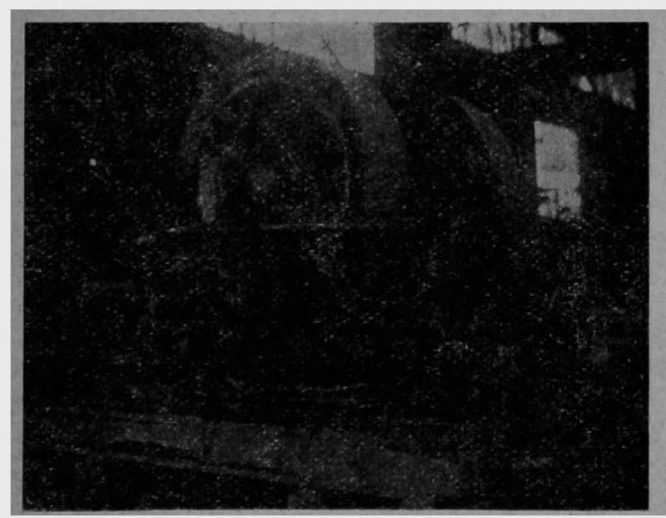

B. インゴツト疪取装置

インゴツト裴面の制れ, 疪, まくれ, 巣の除 去等を目的上したもので下記の諸機器より成つ ている。

a）ニューマチツクチヒングハンマー 2 涸
ビストン消径 $28 \mathrm{~mm}$

b) スカーフイング装置

1 組

スカーフイング吹管:

ビカール式経済酸素調整器

ピカール式アセチレン調整器, 其の他

c） ホータブル・グラインダー(1HP) 3台

C. 補機及附属装证

a) 双鍋関係

1. 取鍋（第13汊） 9 基 容 量 3ton

型、式 ントッバー式

所謂ハツバル，ントッハー者以つて取

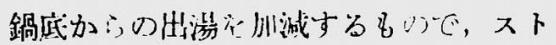

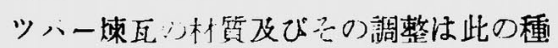
取鍋の生命上も云らへく，其の猢整を简 些且つ確实にする為に特殊の装置が設け られている。

第 13 关

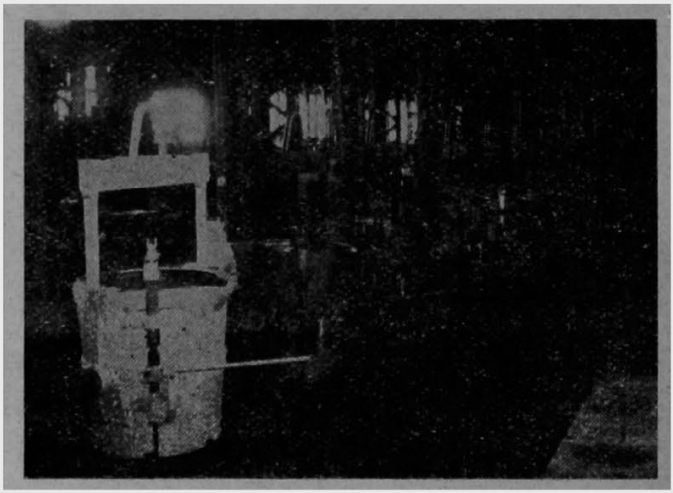

2. 取鍋乾燥妒

之は前記取鍋の乾燥师で，構造上及び 熱効象の観点办的硧 3 基乾燥用 1 基, 2 基用 1 基に分けた。燃料としてコーク ス使用, $2 \mathrm{HP}$ ブロアー付である。

3. スラツグバン 6 個

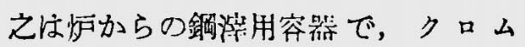
$3 \%$ 程度の耐熱鍀鉄製である。

b) 分析設借 一式 㫮进銅分析汇必恶な諸器具一切を網羅し た。

1. 炭素定量分析装置 1 組

2. 硫带定量分析装置 1 組 
3. サンドバス 3 台 最高温度 $300^{\circ} \mathrm{C}$, 䉓気容量 $8 \mathrm{KVA}$

4. マッフル穴 1 基 最高湿度 $800^{\circ} \mathrm{C}$, 電気容量 $1.5 \mathrm{KVA}$

5. 定温乾燥器 $200 \sim 300^{\circ} \mathrm{C} \quad 1$ 台

6. 蒸溜器 1 台 能力 $51 / \mathrm{h}$, 電気宾量 $4.5 \mathrm{KVA}$

7. 化学用天科 $200 \mathrm{~g}$. 感度 $1 / 10 \mathrm{mg} 3$ 台

8. 㨁立ボール盤

20时, 錐の最大径 $37 \mathrm{~mm} 1$ 台

9. 峏頭グラインダー 㨁立式1HP 1 台

10. 各種温度計，寒暖計 1 維

11. 比重 計

2 組

12. 乳鍊

5 個

13. ガラス器具

ビーカー,フラスコ, 漏斗

ビューレツト，ピペツト，試藕㼯

時計血, メスシリンダー等

14. 万つ㢳

磁製，铜製、ニツヶル整等 各 1 組

15. ゴム器其

1 組

16. 其 0 他

c) 鋳型設備

1 式

$31 / 2$ "角 $\times 5^{\prime}$ 長の鋼塊を上注を゙び下注 きで製造する計画で，客先からは盛儿に 上注字の抱負老伝えて来をが，か」る型 式のインゴツトを上注を゙で作るのは，現 状で壮奖め得ない旨を以口て説得, 結局 下記孝納入した。

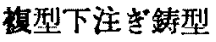

注 入 管

定盤

d）作業用工其

1. 電吊金其

2. 装入へラ

3. 恼修ショベル

4. ハンドランマー

5. デレッキ

6. 二文押棒

7. 定 棒

8. 試料採取器具

9. 金休
250 本

10本

9 個

1 式

3 個

3 倜

6 㛠

10 凬

60 偑

6 偑

6 個

3 組

3 倜
10. 空気压綃機 $15 \mathrm{HP}$

1 台

11.ニューマチック・ランマー 5 㑬

12. 組立用工具

3 組

13. 色 眼鏡 30偑

e) 步 $\infty$ 他
1. 林 料 箱
3 組
2. 工给却用水タンク
3 組
3. 灯蓝煉瓦積台
3 組

f ) 耐火物

1. 酸性炋用

4 組分

(1) シヤモツト整瓦

(2) 非石煉瓦

（3）銀 秒 3 号 6 7 mesh

(4) 䞍石粉 $\begin{cases}20 \mathrm{mesh} & 15 \% \\ 30 \mathrm{mesh} & 35 \% \\ 50 \mathrm{mesh} & 50 \%\end{cases}$

（5）木節粘上 40 mesh 以下

2. 塩基性炉用 $\quad 2$ 組分

(1) シナモツト堜瓦

(2) 珪石煉瓦

(3) クロム・アグネンフ煉瓦

(4) マグネシア $\left\{\begin{array}{c}2 \sim 30 \mathrm{mesh} \\ 70 \sim 75 \% \\ 30 \mathrm{mesh} \text { 以下 } \\ 30 \sim 25 \%\end{array}\right.$

（5）ニールタール(酸性; 塩基性用)

3. 取鍋用媡瓦

4. 耐火モル夕ル

g) 電 極

30 ton

人造黑鉛電極, 值堡 7 时,

以上でスクラッフ熔解から始まつて $3^{1}$ \%"角 メ5”長の鋼塊を作ろ設借まで䅂つたとよになる が，此の鋼塊は次に述へる圧延設简（芝浦共同 工業株式会社製）飞依つて，1/4'南径叭線材， $1 / 2^{\prime \prime}, 5 / 8^{\prime \prime}, 3 / 4^{\prime \prime}, 7 / 8^{\prime \prime}, 1^{\prime \prime}$ ロコンクリート. バー等に圧延される。

V 压延設䚚 (Rolling mill equipments)

此の压延設偖は年間 6,000 時閒稳動よして $1 / 4^{\prime \prime}$ 径の線材を年間 30,000 ton 圧延仙来設 備で次のるのから㭗成されている。
1. 鍓塊スキツド台 2 台
2. 再欮师入ロテーブル
2 台 

3. 再熱六テーブル
2 台
18. 冷間剪断機
1 台
4. 鋼塊押込装置
2 台
5. 鋼塊再熱六
2 基
6. 鋼塊押出機
2 台
7. 压延機入口テーブル
1 式
19. $450 \mathrm{KW}$ 誘尊電動機
1 台 $450 \mathrm{KW}$ 同期電動機
1 台 $600 \mathrm{KW}$ 同期電野
1 台
8. $17^{\prime \prime} \times 17^{\prime \prime} \times 60^{\prime \prime} 3 \varepsilon^{\prime}$ 荒延生延機 1 台 附属機器
1 式
20. 変電設借
1 式

9. チルチングテーブル 1 台

10. 中間コンベアー 1 式

11. 熱間分割剪断機 2 台

12. $11^{\prime \prime} \times 20^{\prime \prime}$ 中間荒延圧延機 1 式

13. 移動型末端紊断機 1 台

14. $11^{\prime \prime} \times 20^{\prime \prime}$ 仕上压延機 1 台

15. 㹂型線条巻取機 2 台

16. 冷却台

1 式

17. 熱間走間剪断機

1 台
VI 鈥瓦工場設備 (Brick manufactnring plant)

製鋼，压延工場の計画に引続いて堜瓦自給の 計画の下に次の機械が発註され，10月最後の結 積を終つた。第14四は当社の指導の下に客先に 於いて設計された工場配置図である。

1. フレット・ミル

1 台

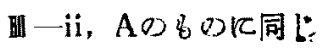

第 14 図 軲瓦工場配置図 (Brick Plant Layout)

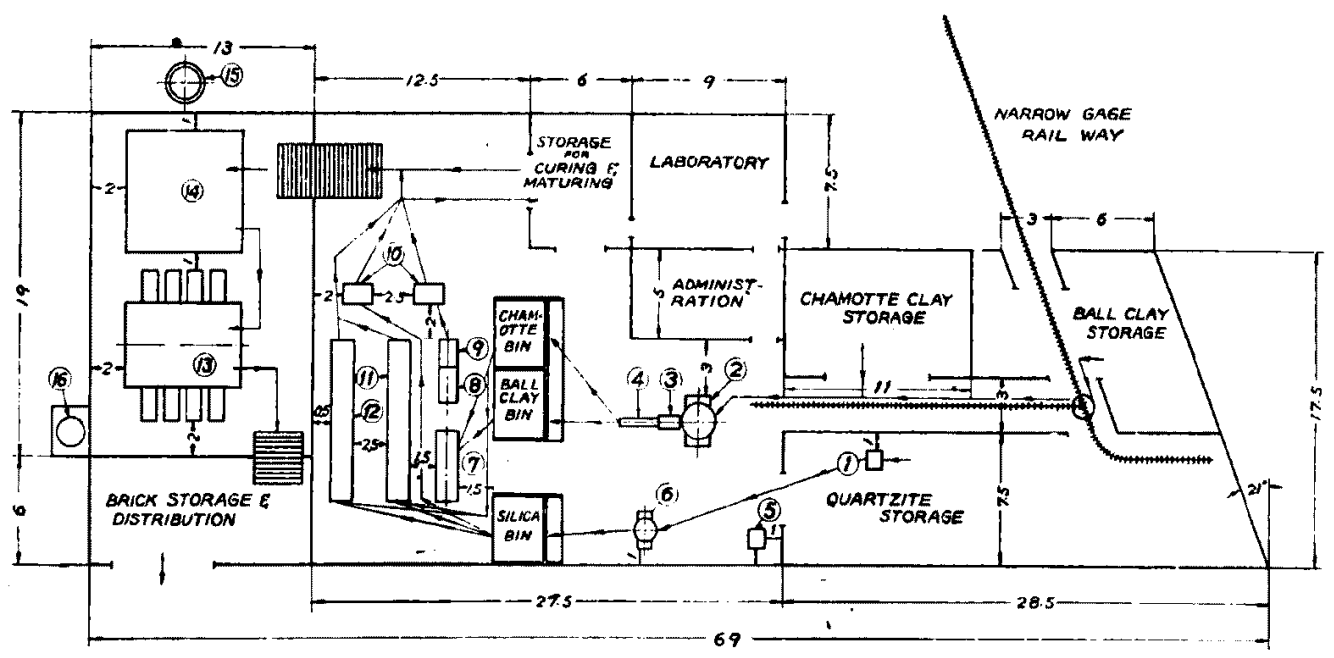

\begin{tabular}{|c|l||c|c|}
\hline No. & \multicolumn{1}{|c|}{ DESCRIPTION } & No. & \multicolumn{2}{|c|}{ DESCRIPTION } \\
\hline 1 & JAW CRUSHER & 9 & CUTTING MACHINE \\
\hline 2 & FRET MILL & 10 & FRICTION PRESS \\
\hline 3 & BUCKET ELEVATOR & 11 & MOLDING PIT \\
\hline 4 & SIEVE & 12 & MOLDING TABLE \\
\hline 5 & MIXER & 13 & OIL-FIRED KILN \\
\hline 6 & WET PAN & 14 & DRYER \\
\hline 7 & PUG MILL & 15 & CHIMNEY \\
\hline 8 & AUGER MACHINE & 16 & OIL SERVICE TANK \\
\hline
\end{tabular}


2. ホリジンタルバグミル

1 台

媡瓦材料混旺用

能 力 : $800 \mathrm{~kg} / \mathrm{h}$

モーター： $3 \mathrm{HP}$

3. ウェツトハン（第15图）

1 台

珪石枯瓦混揘用

能 力 : $80 \mathrm{~kg} / \mathrm{h}$

ハンの㨁径： $900 \mathrm{~mm}$

モーター： $3 \mathrm{HP}$

第 15 図

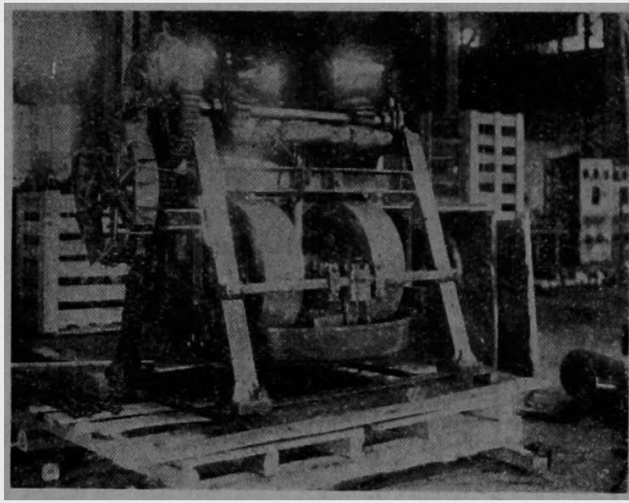

4. ミキサー

1 台

石灰乳製造用(ウェツト・バンに入れる) モーター： $2 \mathrm{HP}$

5. 切断機付横型抜出機（第16図） 1 台 䐈酉混揘, 一次减型用

モーター：10 HP

第 16 図

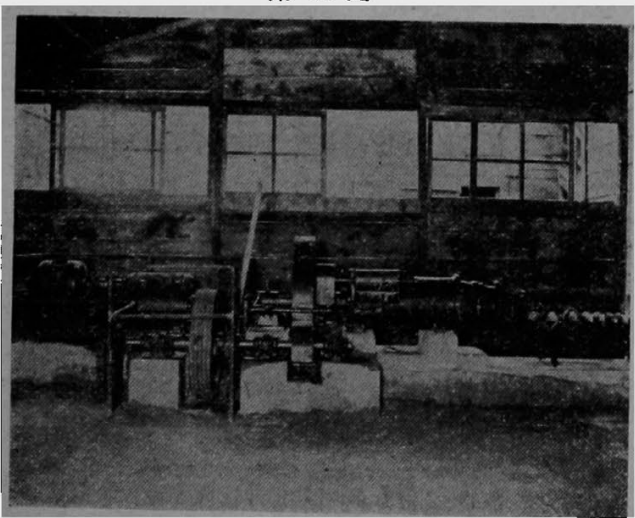

6. 重油焚角型倒焰窟

1 基

煉瓦焼成用。

签 量 : 30 ton

使用温度： $1,350^{\circ} \mathrm{C}$
VI 技術者教育(Training of the Marcelo's engineers)

契䄪之同㭙に先方加方電気工学を修めた技所 が来名，当社星崎工場汇於て製鋼実晢を開始， 続いて圧延，煉瓦作業実習○為次飞之技術者来 名, 今日まで延 8 名の技術者養成をやつて米 た。マルセロ製鍼も当社を在日技術顧問として 新設工場全般の計画に就いて逐一柏談をかけて 机ている第17図は先方派遗技術者 Mr. Cezar Cruz の契留状況である。

第 17 図

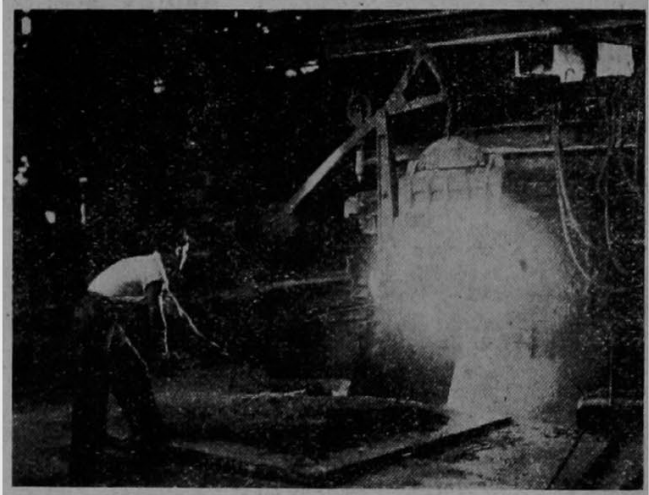

䀩言 (Epilogue)

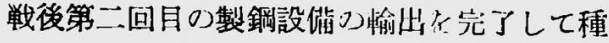
くな経験を重ねた。文書の交換ひみてで応酬をや つて来た関係や，盲貿易に依る不備や，言語，

人情, 猊慣の違いで, いろいるな蓶題にぶつか つて随分世話もやけた。戦福を登り，対日感情 の最ひ悪いと云われるフイリッピンに対し奇し くも斯加る形で再建け一翼を担ら事亡なつた。

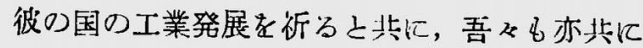
伸びて行き度い亡思う。

最後に本稿を草与るに当り貫重な当瓷料を提 供された前記諸会社り御協力を深㴬し 蘭筆す る。 